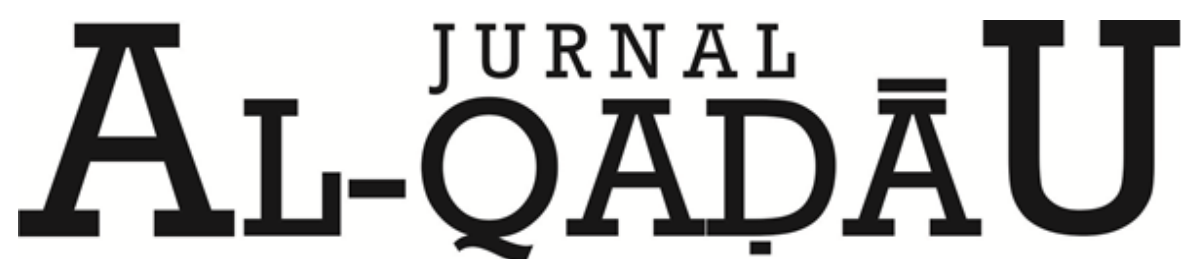 \\ PERADILAN dan HUKUM KELUARGA ISLAM
}

\section{Pencegahan dan Penanggulangan Masalah Kredit Macet bagi Nasabah Perbankan di Kampung Sidomulyo Kabupaten Marauke}

Prevention and Countermeasure Credit Problems for Banking Customers in Sidomulyo Village Merauke Regency

Yuldiana Zesa Azisri

Dosen pada Bagian Hukum Perdata Fakultas Hukum Universitas Musamus Merauke Email : shesaazis@yahoo.com

\begin{tabular}{c|c}
\hline Info & Abstract \\
Artikel & \\
\hline
\end{tabular}

Penelitian ini bertujuan untuk mengetahui upaya apa saja yang dapat digunakan untuk melakukan pencegahan dan penanggulangan masalah kredit macet bagi nasabah perbankan di Kampung Sidomulyo, Kabupaten

Diterima

25

September 2017

\section{Revisi I}

16

Oktober

2017

\section{Revisi II}

13

Nopember

2017

\section{Disetujui}

11

Desember

2017
Merauke, Penelitian ini dilaksanakan di Kabupaten Merauke, Provinsi

Papua Barat. Metode pengumpulan data menggunakan teknik wawancara dan observasi lapangan. Seluruh data, baik data primer maupun data sekunder, dianalisis dengan teknik analisis kualitatif. Hasil penelitian ini menunjukkan bahwa masalah kredit macet dalam halnya terjadinya wanprestasi oleh nasabah di Kampung Sidomulyo Kabupaten Merauke yaitu karena rendahnya pemahaman tentang hukum perbankam yang seharusnya disosialisasikan oleh pihak bank, kurangnya pengetahuan tentang perjanjian kredit oleh nasabah sehingga nasabah tidak mengetahui tentang resiko bila terjadi wanprestasi dan kurangnya pemahaman tentang pencegahan dan penanggulangan kredit macet.

Kata kunci: Kredit macet, Perbankan, Kabaten Merauke.

This study aims to determine what efforts can be used to prevent and mitigate the problem of bad loans for banking customers in Sidomulyo Village, Merauke Regency, this research was conducted in Merauke District, West Papua Province. Methods of data collection using interview techniques and field observation. All data, both primary and secondary data, are analyzed by qualitative analysis technique.The results of this study indicate that the problem of bad debts in the case of the occurrence of wanprestasi by customers in Kampung Sidomulyo Merauke District is due to low understanding of the law perbankam should be disseminated by the bank, the lack of knowledge about credit agreements by customers so that customers are not aware of the risks in case of default and lack of understanding about the prevention and handling of bad debts.

Keywords: Merauke Regency, Credit Problems, Banking. 
Yuldiana Zesa Azis

\section{PENDAHULUAN}

Sebagai Negara berkembang banyak perubahan yang terjadi di semua sektor terutama yang berkaitan dengan ekonomi. Dalam hal ekonomi, seringkali terjadi kendala-kendala yang bisa dikatakan dapat menghambat kelancaran roda pembangunan. Dampak yang ditimbulkan dari kredit macet bagi pihak luar atau eksternal adalah kemungkinan terjadinya erosi kepercayaan baik di lingkungan nasional maupun internasional.

Bank sebagai lembaga keuangan berdasarkan Pasal 1 Ayat (2) Undang-undang perbankan No.10 Tahun 1998 yaitu badan usaha yang menghimpun dana dari masyarakat dalam bentuk simpanan dan menyalurkannya kepada masyarakat dalam bentuk kredit dan atau bentuk-bentuk lainnya dalam rangka meningkatkan taraf hidup rakyat banyak. Dapat kita lihat disini bahwa kredit merupakan salah satu hal terpenting dalam proses berjalannya suatu bank. Semua bidang usaha baik itu perindustrian, perdagangan, konstruksi, properti, pertanian yang merupakan perusahaan dalam golongan besar dan kecil sangat memerlukan kredit dari pihak bank.

Hal ini yang merupakan banyaknya pengajuan kredit baik dari sektor usaha kecil, menengah dan skala besar, namun proses pemberian kredit tidak mudah di bank, para pengusaha harus memenuhi syarat-syarat tertentu untuk mendapatkan kredit di Bank. Sebagaimana aturan pada Pasal 1763 KUHPerdata : siapa yang menerimana pinjaman sesuatu diwajibkan mengembalikan dalam jumlah dan keadaan yang sama. Demikian pula ketentuan pasal 1 ayat (12) Undang-Undang Nomor 10 Tahun 1998 bahwa "Kredit" adalah penyediaan uang atau tagihan yang dapat disamakan dengan itu, berdasarkan persetujuan atau kesepakatan pinjam-meminjam antara bank dengan pihak lain. Pihak peminjam berkewajiban untuk melunasi hutangnya setelah jangka waktu tertentu dengan jumlah bunga, imbalan atau pembagian hasil keuntungan.

Kabupaten Merauke mempunyai perekonomian yang cukup berkembang, Kampung Sidomulyo mempunyai sumber daya alam khususnya di bidang pertanian untuk mengembangkan usaha pertanian diperlukan modal yang cukup karena itulah peran perbankan sangat dibutuhkan untuk membantu dalam meningkatkan produk usaha tani. Namun dalam kenyataannya sering terjadi kredit macet oleh nasabah yang dikerenakan faktor pendapatan pertanian menurun serta ketidakpahaman masyarakat dalam mengelola kredit usaha tani dan kurangnya peran perbankan sebagai pihak 
konsultan dalam membangun pemahaman kepada masyarakat tentang pentingnya pengelolaan kredit usaha yang baik.

\section{PEMBAHASAN}

Kabupaten Merauke adalah salah satu kabupaten yang berada pada wilayah Provinsi Papua dimana secara geografis terletak antara $137^{\circ}-141^{\circ}$ Bujur Timur dan $5^{\circ}$ - $9^{\circ}$ Lintang Selatan. Dengan luas mencapai hingga 46.791,63 $\mathrm{km}^{2}$ atau 14,67 persen dari keseluruhan wilayah Provinsi Papua menjadikan Kabupaten Merauke sebagai kabupaten terluas tidak hanya di Provinsi Papua namun juga di antara kabupaten lainnya di Indonesia. Secara administratif Kabupaten Merauke memiliki 20 distrik, dimana Distrik Waan merupaka distrik yang terluas yaitu mencapai $5.416,84 \mathrm{~km}^{2}$ sedangkan Distrik Semangga adalah distrik yang terkecil dengan luas hanya mencapai $326,95 \mathrm{~km}^{2}$ atau hanya 0,01 persen dari total luas wilayah Kabupaten Merauke. Sementara luas perairan di Kabupaten Merauke mencapai 5.089,71 km².

Luas Kabupaten Merauke adalah 46.791,63 km² (Merauke dalam angka, 2013), yang terdiri dari 20 distrik dengan distrik terjauh adalah distrik Muting yaitu $247 \mathrm{~km}$ dari ibukota kabupaten. Distrik Waan merupakan distrik terluas yaitu mencapai $5.416,84 \mathrm{~km}^{2}$ atau sekitar $11,58 \%$ dari total luas areal diikuti oleh Distrik Ulilin seluas $5.092,57 \mathrm{~km}^{2}$ atau $10,88 \%$.

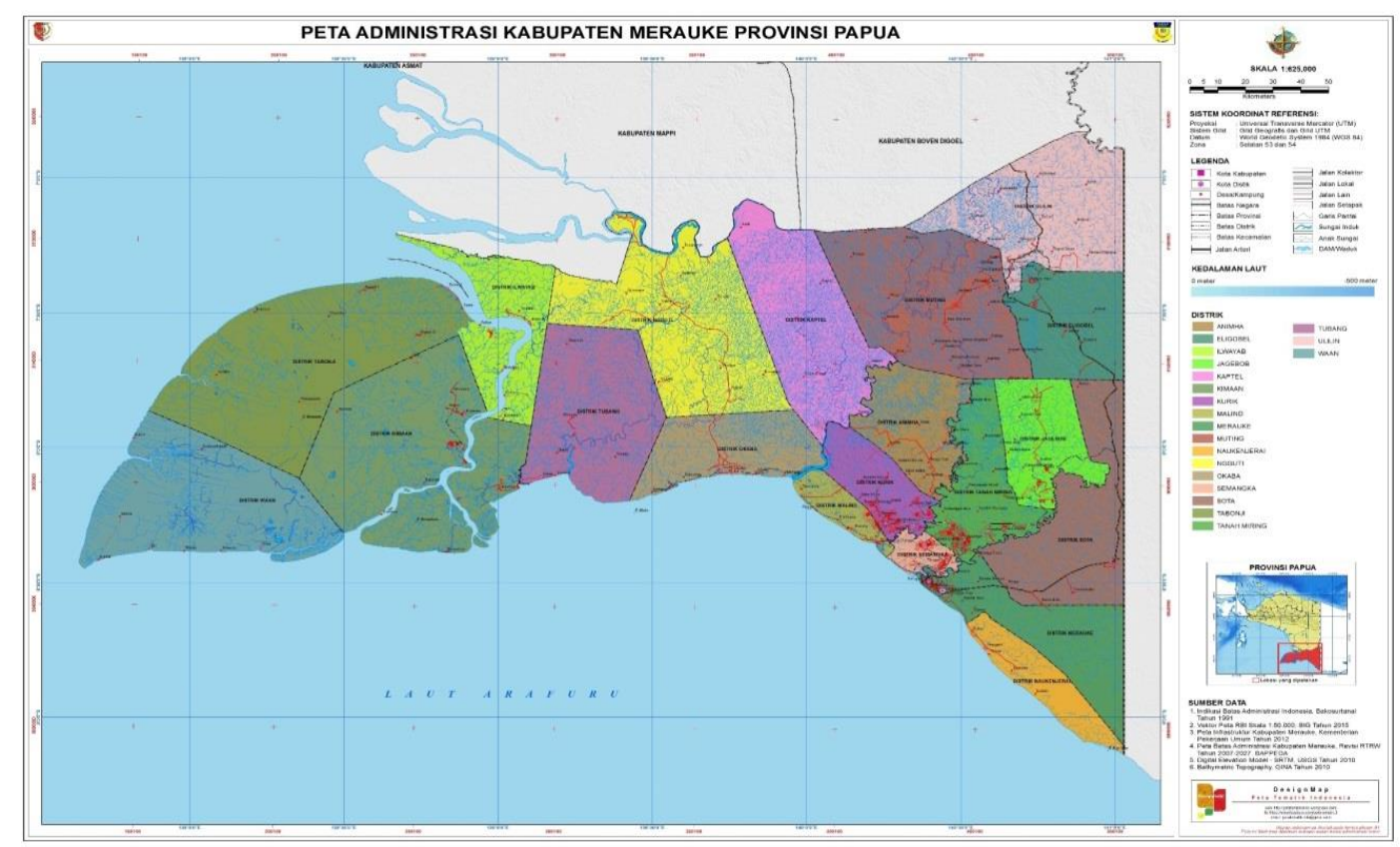


Yuldiana Zesa Azis

Potensi perekonomian di Kabupaten Merauke yang paling menonjol adalah sektor pertanian dan perkebunan karena didukung oleh letak geografis wilayahnya. Selain sektor pertanian, sektor yang mendukung perekonomian Kabupaten Merauke adalah sektor industri, perdagangan dan jasa-jasa. Namun dengan Adanya Bandara MopahMerauke sebagai satu sektor Pengangkutan dan Komunikasi maka menjadi nilai tambah yang jauh lebih tinggi dibanding sektor pertanian dan perkebunan serta sektor lainnya.

Peningkatan nilai tambah terbesar dalam perekonomian Kabupaten Merauke dicapai oleh sektor Pengangkutan dan Komunikasi. Pada tahun 2011 nilai tambah sektor Pengangkutan dan Komunikasi mencapai Rp 177.337,80 Juta rupiah, maka pada tahun 2012 meningkat menjadi sebesar Rp201.456,53 Juta Rupiah atau meningkat sekitar Rp. 24.118,83 Juta rupiah. Peningkatan yang cukup tajam yang terjadi sektor Pengangkutan dan Komunikasi tersebut dipicu dengan adanya peningkatan lalulintas udara dari dan ke Bandara Mopah-Merauke terutama yang terjadi sejak tahun 2012 berkaitan dengan banyaknya kunjungan dari luar Papua dan bertambahnya jumlah maskapai yang masuk ke bandara Mopah-Merauke.

Sementara itu, sektor Pertanian selama tahun 2012 hanya menghasilkan nilai tambah bruto sebesar Rp 725.462,43 juta rupiah atau hanya mengalami peningkatan sekitar Rp 20.017,04 juta rupiah dibandingkan dengan nilai tambah bruto sektor Pertanian selama tahun 2011 yang hanya sebesar Rp. 705,445,39 juta rupiah.

Dari uraian diatas dapat kita ketahui gambaran Kabupaten Merauke. Kampung sidomulyo merupakan daerah pertanian yang rata-rata penduduknya merupakan transmigrasi dari berbagai daerah khususnya daerah Jawa. Dari sektor usaha pertanian masyarakat Kampung Sidomulyo membutuhkan kredit dari pihak bank. Adapun indikator yang berkaitan dengan penyebab kredit macet di Kampung sidomulyo yaitu karena rendahnya pemahaman tentang hukum perbankan yang seharusnya disosialisasikan oleh pihak bank, kurangnya pengetahuan tentang perjanjian kredit oleh nasabah sehingga nasabah tidak mengetahui tentang resiko bila terjadi wanprestasi dan kurangnya pemahaman tentang pencegahan dan penanggulangan kredit macet

Karena itu indikator pencegahan dan penanggulangan kredit macet di Kampung Sidomulyo antara lain : 


\section{Upaya Pencegahan kredit macet di Kampung Sidomulyo}

Adapun yang menjadi penyebab utama timbulnya suatu kredit macet adalah kesulitan-kesulitan keuangan yang dialami oleh penerima kredit. Kesulitan-kesulitan ini timbul karena berbagai faktor. Faktor yang sangat besar pengaruhnya adalah apabila timbul tindakan-tindakan yang tidak efisien dari pimpinan suatu perusahaan, dalam hal mana pimpinan perusahaan mempunyai berbagai kelemahan dalam mengelola perusahaan, kelemahan dalam kontrol, ataupun kesalahan dalam penentuan kebijaksanaan perusahaan.

\section{Pengawasan dan Pembinaan oleh bank}

Pengawasan oleh bank terbagi menjadi dua yaitu pengawasan aktiv dan pasif. pengawasan aktiv yaitu pengawasan yang dilakukan di tempat usaha debitur sehingga dapat diketahui setiap permasalahan yang terjadi.

Pengawasan pasif yaitu pengawasan tertulis yang dilakukan debitur, seperti laporan keadaan keuangan, laporan penyaluran keuangan, laporan aktivitas, pembukuan, dll.

Fungsi monitoring dan pengawasan kredit merupakan alat kendali apakah dalam pemberian kredit telah dilaksanakan sesuai dengan perencanaan maupun ketentuanketentuan yang telah ditetapkan di bidang perkreditan, yaitu dalam bentuk surat edaran atau peraturan ataupun ketentuan-ketentuan lain yang berlaku secara umum maupun khusus.

Pelaksanaan fungsi pengawasan ini merupakan tanggung jawab setiap level manajemen ataupun setiap individu yang mengelola kegiatan di bidang perkreditan pada masing-masing bank atau cabang. Sehingga pada hakikatnya, kegiatan pengawasan perkreditan bersifat melekat di dalam organisasi dan prosedur kerja yang ada yang dikelola masing-masing level manajemen/ individu tersebut.

Sementara itu, fungsi pengawasan yang dilakukan oleh unit pengawasan eksternal, internal auditor lainnya merupakan sarana untuk melakukan re-checking dan dinamisator apakah internal control di bidang perkreditan telah berjalan sebagaimana mestinya. ${ }^{1}$

\footnotetext{
${ }^{1}$ http://informasitraining-indonesia.com/tag/struktur-pengawasan-kredit/
} 
Yuldiana Zesa Azis

\section{Penyelematan oleh bank}

Adalah suatu langkah penyelesaian kredit bermasalah melalui perundingan kembali antara bank sebagai kreditor dan nasabah peminjam sebagai debitor, mengenai penyelamatan kredit bermasalah dapat dilakukan dengan berpedoman kepada Surat Edaran Bank Indonesia No. 26/4/BPPP tanggal 29 Mei 1993 yang pada prinsipnya mengatur penyelamatan kredit bermasalah sebelum diselesaikan melalui lembaga hukum adalah melalui alternatif penanganan secara:

1. penjadwalan kembali (rescheduling),

2. persyaratan kembali (reconditioning),

3. dan penataan kembali (restructuring).

Penyelamatan kredit bermasalah yang umum dilakukan dengan menggunakan $3 \mathrm{R}$.

Syarat Penyelamatan Kredit Bermasalah Bank / Lembaga Keuangan melakukan upaya penyelamatan kredit bermasalah dengan pertimbangan sebagai berikut:

a. Dengan penyelamatan kredit, kondisi Bank / Lembaga Keuangan menjadi lebih baik.

b. Adanya itikad baik dari debitur yang kooperatif.

c. Penilaian usaha debitur yang menunjukkan prospek usaha yang baik.

d. Penilaian harga barang jaminan dapat digunakan untuk menutup kredit, jika masih kurang nilai jaminannya maka debitur harus memberikan jaminan lagi.

Dalam surat edaran tersebut yang dimaksud dengan penyelamatan kredit bermasalah melalui rescheduling, reconditioning, dan restructuring adalah sebagai berikut:

1. Melalui rescheduling (penjadwalan kembali), yaitu suatu upaya hukum untuk melakukan perubahan terhadap beberapa syarat perjanjian kredit yang berkenaan dengan jadwal pembayaran kembali/ jangka waktu kredit termasuk tenggang (grace priod), termasuk perubahan jumlah angsuran. Bila perlu dengan penambahan kredit.

2. Melalui reconditioning (persyaratan kembali), yaitu melakukan perubahan atas sebagian atau seluruh persyaratan perjanjian, yang tidak terbatas hanya kepada perubahan jadwal angsuran, atau jangka waktu kredit saja. Tetapi perubahan kredit tersebut tanpa memberikan tambahan kredit atau tanpa melakukan konversi atas seluruh atau sebagian dari kredit menjadi equity perusahaan. 
3. Melalui restructuring (penataan kembali), yaitu upaya berupa melakukan perubahan syarat-syarat perjanjian kredit berupa pemberian tambaha kredit, atau melakukan konversi atas seluruh atau sebagian kredit menjadi perusahaan, yang dilakukan dengan atau tanpa rescheduling atau reconditioning Restrukturisasi Kredit adalah upaya perbaikan yang dilakukan Bank dalam kegiatan perkreditan terhadap debitur yang mengalami kesulitan untuk memenuhi kewajibannya, yang dilakukan antara lain melalui:
a. penurunan suku bunga Kredit;
b. perpanjangan jangka waktu Kredit;
c. pengurangan tunggakan bunga Kredit;
d. pengurangan tunggakan pokok Kredit;
e. penambahan fasilitas Kredit; dan atau
f. konversi Kredit menjadi Penyertaan Modal Sementara

Praktek penyelesaian masalah kredit macet diawali dengan upaya - upaya dari bank sebagai pihak kreditur dengan berbagai cara antara lain dengan melakukan penagihan langsung oleh bank kepada debitur yang bersangkutan atau mengupayakan agar debitur menjual agunan kreditnya sendiri untuk pelunasan kreditnya di bank.

\section{Upaya Penanggulangan Kredit Macet di Kampung Sidomulyo}

\section{Penagihan oleh pihak perbankan}

Sebagaimana diketahui dalam praktek penyelesaian masalah kredit macet diawali dengan upaya - upaya dari bank sebagai pihak kreditur dengan berbagai cara antara lain dengan melakukan penagihan langsung oleh bank kepada debitur yang bersangkutan atau mengupayakan agar debitur menjual agunan kreditnya sendiri untuk pelunasan kreditnya di bank.

Apabila penyelesaian sebagaimana tersebut diatas tidak berhasil dilaksanakan, pada umumnya upaya yang dilakukan bank dilakukan melalui prosedur hukum. Sehubungan dengan hal tersebut, sesuai dengan peraturan perundang-undangan yang berlaku terdapat beberapa lembaga dan berbagai sarana hukum yang dapat dipergunakan untuk mempercepat penyelesaian masalah kredit macet perbankan. 
Yuldiana Zesa Azis

\section{Perdamaian para pihak}

Dalam kasus gagal bayar alias kredit macet di sini mungkin penyelesaiannya bisa lewat bantuan Mediasi Perbankan seperti yang diamantkan dalam Peraturan Bank Indonesia (PBI) No 8/5/PBI/2006. Mediasi ini pun dilakukan jika sebelumnya tidak menemukan titik terang dengan pihak internal bank. Bank Indonesia akan berperan sebagai penengah dan mediator yang netral antara nasabah dan bank. Penyelesaian sengketa lewat mediasi perbankan punya sejumlah keunggulan, seperti:

1. Gratis

2. Jangka waktu mediasi paling lama 60 hari kerja sejak penandatangan perjanjian mediasi

3. Prosesnya dilakukan secara informal dan fleksibel

Sengketa dapat diselesaikan mediasi perbankan apabila memenuhi kriteria di bawah ini :

1. Bila nasabah tak puas dengan solusi dari saluran pengaduan nasabah di bank

2. Sengketa yang dapat diajukan penyelesaiannya bila nilainya di bawah $\operatorname{Rp} 500$ juta

3. Belum pernah dimediasi sebelumnya baik oleh BI atau lembaga mediasi lainnya

4. Tidak dalam proses atau telah diputus lembaga arbitrase atau pengadilan. Atau belum ada kesepakatan yang dimediasi lembaga lainnya seperti Pusat Mediasi Nasional (PMN), Badan Penyelesaian Sengketa Konsumen (BPSK), Lembaga Perlindungan Konsumen Swadaya Masyarakat (LPKSM), dan lainnya.

5. Sengketanya belum kadaluwarsa, yaitu sengketa yang masa pengaduannya belum melampaui 60 hari kerja sejak disampaikan bank kepada nasabah.

Dalam upaya tersebut, Bank Indonesia akan mempertemukan antara nasabah dan bank guna mencari penyelesaian serta mengarahkan pihak yang bersengketa untuk mencari penyelesaian. BI juga tak memberikan rekomendasi atau keputusan. Sebisa mungkin kesepakatan berasal dari pihak yang bersengketa.

\section{Penyelesaian kredit melalui jalur hukum}

Suatu langkah penyelesaian kredit bermasalah melalui lembaga hukum. Yang dimaksud dengan lembaga hukum dalam hal ini adalah Panitia Urusan Piutang Negara (PUPN) dan Direktorat Jendral Piutang dan Lelang Negara (DJPLN), melalui Badan Peradilan, dan melalui Arbitrase atau Badan Alternatif Penyelesaian sengketa. Apabila 
penyelesaian sebagaimana tersebut diatas tidak berhasil dilaksanakan, pada umumnya upaya yang dilakukan bank dilakukan melalui prosedur hukum. Sehubungan dengan hal tersebut, sesuai dengan peraturan perundang-undangan yang berlaku terdapat beberapa lembaga dan berbagai sarana hukum yang dapat dipergunakan untuk mempercepat penyelesaian masalah kredit macet perbankan.

\section{Penyelesaian Kredit Bermasalah Secara Damai.}

Penyelesaian kredit bermasalah secara damai dapat dilakukan terhadap debitur yang beritikad baik untuk menyelesaikan kewajibannya dan cara yang ditempuh dalam penyelesaian ini dianggap lebih baik dibandingkan alternatif penyelesaian melalui saluran hukum.

Jenis-Jenis dan Ketentuan Penyelesaian Kredit Secara Damai, meliputi:

- Pemberian fasilitas keringanan bunga, Pemberian fasilitas keringanan bunga hanya diberikan kepada penunggak dengan kolektibilitas Diragukan, Macet dan Kredit yang telah dihapus bukukan.

- Penjualan agunan di bawah tangan, Penjualan agunan di bawah tangan dilakukan agar debitur masih diberikan kesempatan untuk menawarkan/menjual sendiri agunannya.

\section{Eksekusi Jaminan}

Melihat pada bentuk-bentuk prestasi pada Pasal 1234 KUHPer serta pendapat J. Satrio dalam bukunya yang berjudul Hukum Perikatan (hal. 122), dapat kita lihat bahwa wujud wanprestasi bisa berupa:

1. Debitur sama sekali tidak berprestasi;

2. Debitur keliru berprestasi;

3. Debitur terlambat berprestasi.

Apabila kredit macet tersebut terjadi karena debitur tidak melaksanakan prestasinya sebagaimana terdapat dalam perjanjian kredit, maka sebelum melakukan eksekusi barang jaminan, debitur harus terlebih dahulu dinyatakan wanprestasi, yang dilakukan melalui putusan pengadilan. Untuk itu kreditur harus menggugat debitur atas dasar wanprestasi. Akan tetapi sebelum menggugat debitur, kreditur harus melakukan somasi terlebih dahulu yang isinya agar debitur memenuhi prestasinya. Apabila debitur tidak juga memenuhi prestasinya, maka kreditur dapat menggugat debitur atas dasar 
Yuldiana Zesa Azis

wanpretasi, dengan mana apabila pengadilan memutuskan bahwa debitur telah wanprestasi, maka kreditur dapat melakukan eksekusi atas barang jaminan yang diberikan oleh debitur. Jadi, dapat atau tidaknya barang jaminan dieksekusi tidak hanya bergantung pada apakah jangka waktu pembayaran kredit telah lewat atau tidak. Akan tetapi, apabila debitur melakukan prestasi yang tidak sesuai dengan yang diperjanjikan, itu juga merupakan bentuk wanprestasi (keliru berprestasi atau melakukan tidak sebagaimana yang diperjanjikan) dan dapat membuat kreditur berhak untuk melaksanakan haknya mengeksekusi barang jaminan.

\section{PENUTUP}

Adapun yang dapat menimbulkan terjadinya kredit macet antara lain Adalah kesulitan -kesulitan keuangan yang dialami oleh penerima kredit atau kreditur. Keadaan perekonomian seperti gagal panen dan pembayaran kredit yang telah jatuh tempo. Timbulnya kredit macet pada Kampung Sidomulyo Kabupaten Merauke sangat mempengaruhi karena ketidak pahaman nasabah terhadap pelaksanaan perjanjian kredit yang telah dibuat dengan krediturnya.

Faktor - faktor penyebab dari kredit macet itu sendiri dapat disebabkan oleh pihak kreditur (bank) ataupun debitur (nasabah). Kesalahan dari pihak kreditur seperti : keteledoran bank mematuhi peraturan pemberian kredit yang telah digariskan; terlalu mudah memberikan kredit, yang disebabkan karena tidak ada patokan yang jelas tentang standar kelayakan permintaan kredit yang diajukan; konsentrasi dana kredit pada sekelompok debitur atau sektor usaha yang beresiko tinggi; dan lain - lain. Sedangkan faktor yang disebabkan oleh debitur diantaranya : karena rendahnya pemahaman tentang hukum perbankan yang seharusnya disosialisasikan oleh pihak bank, kurangnya pengetahuan tentang perjanjian kredit oleh nasabah sehingga nasabah tidak mengetahui tentang resiko bila terjadi wanprestasi dan kurangnya pemahaman tentang pencegahan dan penanggulangan kredit macet 
Untuk menyelesaikan dan menyelamatkan kredit yang dikategorikan macet, dapat ditempuh usaha-usaha sebagai berikut :

1. Rescheduling (Penjadwalan Ulang)

2. Reconditioning (Persyaratan Ulang)

3. Restructuring (Penataan Ulang) 


\section{DAFTAR PUSTAKA}

Darus, Badrul Zaman, Mariam. Perjanjian Kredit Bank, Penerbit PT. Citra Aditya Bakti, Bandung, 1991.

Munir, Fuady. Hukum Perkreditan Kontemporer, Penerbit PT Citra Aditya Bakti, Bandung, 2002.

Hermasnyah. Hukum Perbankan Nasional Indonesia, Penerbit Kencana Prenada Media, Jakarta, 2005.

Ritonga, Sri Kartika. Upaya Bank Dalam Mencegah dan Menyelesaikan kredit macet, Usu Resporsitory, 2009. 